\title{
Limitations and caveats of magnetic cell labeling using transfection agent complexed iron oxide nanoparticles.
}

Stefaan J. Soenen, Stefaan C. De Smedt and Kevin Braeckmans*

Lab of General Biochemistry and Physical Pharmacy, Faculty of Pharmaceutical Sciences, Ghent University, Harelbekestraat 72, B-9000 Gent, Belgium

*Corresponding author: Email: Kevin.Braeckmans@ugent.be 


\begin{abstract}
Cell labeling with various types of nanomaterial, such as FDA-approved iron oxide nanoparticles (IONPs) has become common practice in biomedical research. The low uptake of IONPs stimulates the use of transfection agents (TA), but the effect on stability of the IONPs and their cellular interactions has received minimal attention. In the present study, we evaluated the use of Lipofectamine as a commonly used TA and tested different ratios of TA and IONPs. While the TA-IONP complexes are stable in saline, at a high ratio of TA over IONP, substantial aggregation occurred in serum-containing media. Even for the highest ratio, TA was unable to completely cover the IONPs, resulting in a net negative charge of all complexes. At high TA-IONP ratios, more complexes remained surface-associated without internalization, resulting in cell death, while at lower TA-IONP ratios, complexes were more avidly taken up through fluid-phase pinocytosis and clathrin-mediated endocytosis. At later time points, the endocytosed complexes accumulated within the lysosomes and affected the appearance of lysosomal structures. The data indicate that TAs should be used with care as, depending on the ratio of TA and IONP, the complexes may aggregate, inducing cell death and preventing internalization.
\end{abstract}




\section{Introduction}

In biomedical research, iron oxide nanoparticles (IONPs) have been widely applied in several fields, including targeted drug (1) or gene (2) delivery or magnetic hyperthermia (3), but foremost as magnetic resonance imaging (MRI) contrast agents (4). A wide variety of IONPs are available, varying in size from a few nanometers to over 1 micrometer and having coating materials ranging from synthetic polymers, lipids or dextran to small molecules (5-9). To date, dextran-coated iron oxide cores (Endorem in Europe, Feridex in the USA) have been most widely applied and have been used extensively in clinical settings for the detection of liver pathologies. As one of the sole FDA-approved iron oxide formulations for direct intravenous injection, these particles have also been employed more frequently in biomedical research as agents for the magnetic labeling of (stem) cells. In 2008, however, Feridex production for the US market by AMAG Pharmaceuticals Inc. was stopped, impeding further advancements in this field. The particles still remain popular, however, as several clinical trials have been set up, all outside of the USA, using Endorem-labeled stem cells to evaluate the homing of these cells by serial MR tracking after transplantation (10). Furthermore, owing to its long-time use in biomedicine, many data regarding interactions with tissues and cells are available, making it an ideal research tool.

One of the key issues which is still a matter of debate is the possible influence of Endorem particles on the cellular wellbeing. Several groups have recently shown that high levels of Endorem can affect cell proliferation and cellular morphology $(9,11)$, where intracellular degradation may induce reactive oxygen species (ROS) and affect stem cell functionality (1216). An in-depth evaluation of the potential (cytotoxic) effects of IONPs on cultured cells is therefore of primordial importance in order to stimulate any further progress in this field. Furthermore, the efficiency of combining Endorem and transfection agents (TAs) to promote cellular uptake is still questionable as several reports hint at an increased uptake (17), whereas others describe only surface association and no cellular internalization (18). Such surfacebound particles have been described to potentially impair cell homeostasis (19) and are also more likely to be desorbed from the cells after transplantation in vivo, greatly impeding the accuracy of any noninvasive imaging methods. For efficient and accurate MRI cell tracking, it is therefore highly beneficial if the IONPs are cell-internalized, where high numbers of cell surface-associated IONPs will endanger any further uses of these cells in an in vivo setting. 
A first step in clarifying the complex interactions between IONPs and cultured cells consists of evaluating the uptake mechanism and the intracellular localization of the particles. Endorem particles as such are reported to be generally taken up by means of fluid phase pinocytosis, reaching quite low intracellular nanoparticles levels (7). To increase cellular uptake, it has been suggested to complex Endorem with commercial transfection agents such as protamine, poly-L-lysine or Lipofectamine prior to cell labeling $(17,20)$. The effect of the transfection agents on the stability of Endorem in physiological buffer and the resulting interactions with cultured cells has only rarely been addressed (21). The present work therefore aims to investigate the effect of Lipofectamine as one of the most frequently used commercial cationic transfection agents. Furthermore, the interactions of these complexes with cervical cancer cells (HeLa) has been studied in terms of uptake mechanisms and internalization efficiency. The obtained results will allow evaluation og whether complexation of Lipofectamine with Endorem affects the stability of the complexes in dispersion and will provide insight into the precise intracellular localization and uptake efficiency of the particles. This will render it feasible to evaluate whether the addition of Lipofectamine is beneficial or detrimental for efficient cell labeling strategies and will help to point out possible shortcomings and drawbacks associated with the addition of this transfection agent.

\section{Results and discussion.}

\subsection{Effect of lipofectamine on size and surface charge of endorem complexes.}

Endorem consists of several $4 \mathrm{~nm}$-diameter iron oxide nanocores that are embedded in a neutral dextran matrix, leading to a rather high variation in the number of iron oxide cores per particle and in the total size of the particles typically from 60 to $150 \mathrm{~nm}$ (5). During preparation, small amounts of citric acid are used, which can lead to the presence of several carboxyl groups on the dextran shell and induce a slightly negative surface potential (22). This negative charge enables efficient complexation with cationic transfection agents, such as Lipofectamine. Lipofectamine 2000 as used in the present work is a commercially available formulation which consist of the polycationic lipid 2,3-dioleyl-N[2(sperminecarboxamido)ethyl]-N,N-dimethyl-1-propanaminium trifluoro-acetate and the neutral lipid in a 3:1 ratio. This formulation has been described to show lower cytotoxic effects compared with previous formulations and has also been found to remain functional in 
serum-containing media (23). Typically, Endorem and Lipofectamine are mixed in phosphatebuffered saline (PBS) and allowed to form stable complexes for $1 \mathrm{~h}$ prior to further dilution in cell media and application to cultured cells (17). Table 1 shows the hydrodynamic diameter as measured by dynamic light scattering of pure Endorem or after complexation with Lipofectamine at 3 different ratios $\left(100 \mu \mathrm{g} \mathrm{Fe} \mathrm{ml}^{-1}\right.$ and $2.5,5$ or $10 \mu \mathrm{g} \mathrm{ml}^{-1}$; these ratios are kept constant throughout the work, so that, when lower Endorem quantitities are used later on in the work, the amount of Lipofectamine is reduced accordingly) as a function of time and the surface potential of the complexes after $30 \mathrm{~min}$. The data show that, in agreement with the literature (5), Endorem particles are rather polydisperse in size, but appear to be quite stable in PBS. Addition of Lipofectamine moderately increases the size of the complexes, in correlation to the amount of Lipofectamine added. Additionally, the complexes appear to be formed rapidly as no clear differences in sizes can be seen throughout the entire time-span of the experiment. Interestingly, after 30min, the surface charge of the complexes is only slightly altered after addition of Lipofectamine as, in all conditions, a net negative surface charge ismaintained. This trend was observed in three independent batches of TA-IONP complexes, of which the average value is given in Table 1 . The relatively low value obtained for free Endorem of about $-6 \mathrm{mV}$ may be explained by the fact that measurements were performed in serum-free but $\mathrm{Ca}^{2+}$ - and $\mathrm{Mg}^{2+}$-containing PBS. The latter ions might electrostatically interact with the negative surface and hereby result in only a very small negative $\zeta$-potential. The standard deviation increases with higher amounts of Lipofectamine, which may indicate an increased variability in surface charges between individual complexes. Taken together, these data show that the addition of Lipofectamine cannot reverse the overall surface charge of the Endorem complexes. We hypothesize that a substantial part of the Endorem surfaces remains unbound, while the other part becomes partially or completely coated with Lipofectamine, leading to local positive charges, which is beneficial for promoting attachment to the cell surface (Scheme 1a, b).

\subsection{Cell association of Endorem-Lipofectamine complexes.}

In order to investigate the interactions of the Endorem-Lipofectamine complexes with cultured cells, HeLa cells were exposed to serum-containing cell media containing the different complexes at $100 \mu \mathrm{g} \mathrm{Fe} \mathrm{ml}{ }^{-1}$ for $8 \mathrm{~h}$ and then stained for iron by means of diaminobenzidine (DAB)-enhanced Prussian blue staining. The complexes were incubated at three different ratios of Endorem and Lipofectamine $\left[100 \mu \mathrm{g} \mathrm{Fe} \mathrm{ml}^{-1}\right.$ and 10 (Endo H), 5 
(Endo M) and $2.5 \mu 1 \mathrm{ml}^{-1}$ (Endo L)]. Throughout this work, Lipofectamine concentrations were kept at maximally $10 \mu \mathrm{ml}^{-1}$ as from earlier studies and our own experience, significant cytotoxic effects are induced when using higher Lipofectamine amounts (17). HeLa cells were either incubated at $37{ }^{\circ} \mathrm{C}$ to allow normal endocytosis to occur or at $4{ }^{\circ} \mathrm{C}$ to block all active endocytic transport pathways and therefore only allowing cellular attachment of the complexes. Incubation also occurred at $37^{\circ} \mathrm{C}$ with HeLa cells expressing mutant dynamin, an important mediator in several endocytic processes to validate that the TA-IONP complexes are internalized by active endocytosis mechanism(s). Figure 1 shows representative images of HeLa cells incubated with Endorem-Lipofectamine complexes [100 $\mu \mathrm{g} \mathrm{Fe} \mathrm{ml}^{-1}$ and 10, 5 and $2.5 \mu 1 \mathrm{ml}^{-1}$ Lipofectamine (a, b and c)] for cells incubated at $37{ }^{\circ} \mathrm{C}$ (first row), cells incubated at $4{ }^{\circ} \mathrm{C}$ (second row) and mutant dynamin expressing cells (third row). For knockdown of dynamin, HeLa dyn K44A cells were used, which express a tetracycline (TET)-inducible dominant negative form of dynamin-1, as developed by the S. L. Schmid group (24). The images clearly show a great increase in total levels of NP-cell association correlating to higher Lipofectamine ratios, which is most pronounced when incubation occurred at $4{ }^{\circ} \mathrm{C}$. Also, for the highest amount of Lipofectamine (a), the whole microscopy coverslip was covered with aggregates which stained positive for DAB-enhanced Prussian blue, indicating aggregation and sedimentation of the complexes in full cell media. These aggregates were only scarcely observed for medium or low Lipofectamine ratios $(b, c)$. Scheme 1 presents a schematic overview of the stability of dispersed Endorem complexes, for free Endorem in saline (a), Lipofectamine-complexed Endorem in saline (b) and Lipofectamine-complexed Endorem in serum (c). Note that our data indicate colloidal stability of the complexes in saline (Scheme 1a, b), whereas aggregates are formed when serum is present (Scheme 1c), which may be caused by serum proteins that act as bridges between Lipofectamine covered complexes. Incubation of the cells at $4{ }^{\circ} \mathrm{C}$ still led to positive DABenhanced Prussian blue stainings in all conditions, albeit the total amount of iron detected was clearly lower than those for cells incubated at $37{ }^{\circ} \mathrm{C}$. The high level of aggregation and cell surface attachment at high Lipofectamine amounts make the difference between $37{ }^{\circ} \mathrm{C}$ and $4{ }^{\circ} \mathrm{C}$ less obvious, but the results for medium and low amounts of Lipofectamine are quite clear. As all active endocytic processes are blocked at $4{ }^{\circ} \mathrm{C}$, the positive staining probably indicate cell surface-associated complexes (probably aggregates) rather than internalized complexes. This is also suggested by the images at lower Lipofectamine concentrations (Fig. 1 b,c), which display positive stainings predominantly at the cell periphery. Mutant dynamin expressing cells also clearly 
display a far lower level of iron than cells incubated at $37{ }^{\circ} \mathrm{C}$, which would indicate that a significant portion of the complexes is internalized by means of a dynamin-dependent endocytic process. Taken together, these experiments show a clear endocytosis-driven uptake mechanism.

Compared with pure Endorem particles (Fig. 1e), the addition of Lipofectamine clearly enhances cellular association of the complexes, for all TA-IONP ratios. Probably, the incomplete surface covering of the IONPs by the TA will lead to a high heterogeneity in local surface charges, increasing the affinity of charged serum proteins to the complex surface, leading to a so-called protein corona (25). Furthermore, it has been found that the thickness of the adsorbed protein layer correlates with the size of the NPs (26), hinting at a higher number of proteins binding on the complexes with higher Lipofectamine contents. As single charged proteins may bind differences complexes, these proteins may act as bridges and thereby induce further interaction of the complexes with one another through the bound proteins and lead to aggregation (Scheme 1c). The association of serum proteins will also influence the way the complexes areinteracting with the cells, as recently shown for silver and gold NPs of similar sizes (27) or differences in NP stability and cell-nanoparticle (NP) interactions, depending on the type of culture medium used (28). The degree of aggregation clearly depends on the ratio of Lipofectamine over Endorem and seemed much less where the Lipofectamine amount was kept at $5 \mathrm{ml} \mathrm{ml}^{-1}$ or below. These findings (the influence of cell media type and Lipofectamine-Endorem ratios) might explain the ambiguity in published data where Endorem-transfection agent complexes were described as well internalized (17), led to high amounts of cell surface association and internalization $(14,22)$, or solely led to surface attachment (18).

\subsection{Quantitative uptake and cell-association levels.}

In order to evaluate in more detail the effect of complex composition on the number of surface-associated complexes over internalized ones, the amount of cell-associated iron was quantified, as shown in Fig. 2. In Fig. 2(a), the total cellular iron content of mutant dynamin expressing HeLa cells or HeLa cells incubated for $24 \mathrm{~h}$ at 4 or $37{ }^{\circ} \mathrm{C}$ with the various Endorem-Lipofectamine complexes at $50 \mu \mathrm{g} \mathrm{Fe} \mathrm{ml} l^{-1}\left(1.25,2.5\right.$ and $5 \mu \mathrm{ml}^{-1}$ Lipofectamine) or in the absence of any complexes (negative controls) is shown. The lower iron content was 
selected in order to remain within the linear region of the iron determination method and to reduce the number of aggregates. The data show that untreated cells contain nearly no iron, as expected, but exposure of the cells to the complexes greatly enhances the total cellular iron content. The amount of cell-associated complexes increases for higher ratios of Lipofectamine over Endorem in all three conditions. The amount of cell-associated iron is minimal at $4{ }^{\circ} \mathrm{C}$ in every condition, and reflects 40,49 and $59 \%$ of the total cell-associated iron (= the amount of iron measured for normal HeLa cells incubated with the complexes at $37{ }^{\circ} \mathrm{C}$ under identical conditions), for higher Lipofectamine ratios. This suggests that, for higher amounts of Lipofectamine, more merely surface-associated iron was found that was not internalized by the cells. Data of mutant dynamin-expressing cells show a higher amount of cell-associated iron than cells incubated at $4{ }^{\circ} \mathrm{C}$, but significantly less than in cells incubated at $37{ }^{\circ} \mathrm{C}$. This indicates that dynamin is only partially involved in the internalization of the complexes and that the complexes are probably internalized by different endocytic processes. Based on these data, it can be concluded that large amounts of surface-associated iron are intrinsically linked to the addition of Lipofectamine. We note that, for an incubation time of $4 \mathrm{~h}$, similar data were obtained as for $24 \mathrm{~h}$, with the only difference being that the overall amount of cellassociated iron was slightly smaller (data not shown).

Based on these results we decided to use only medium amounts of Lipofectamine for further experiments $\left(2.5 \mu \mathrm{ml}^{-1}\right.$ and $50 \mathrm{mg} \mathrm{Fe} \mathrm{ml}^{-1}$ Endorem), since this allows substantial uptake to be achieved while avoiding excessive aggregation and sedimentation of large complexes, as was observed for the highest TA concentration (cf. Scheme 1a). In order to further elucidate the endocytic routes involved, we have applied a number of pharmacological inhibitors (29). Incubation of the cells with the complexes and treatment with the carefully selected concentrations of inhibitors did not affect cell viability as assessed by lactate dehydrogenase and mitochondrial metabolism assays after 4 and $24 \mathrm{~h}$ (data not shown). Figure 2(b) shows the cellular iron content of control cells or cells treated with pharmacological endocytosis inhibitors. From these data, it can be seen that Noco and cytochalasin D (Cyt D), which depolymerizes actin microfilaments, both greatly inhibit uptake of the complexes. Maximal inhibition (52\% reduction) could be noted when cells were exposed to a combination of both inhibitors, which is in line with previous reports where Noco + Cyt D have been described to completely block all intracellular routing (30). The level of iron found was similar to the amount of cell-associated iron obtained when incubation occurred at $4{ }^{\circ} \mathrm{C}$, indicating that this 
comes from surface-associated complexes. Chlorpromazine (CPM), a cationic amphiphilic drug, inhibits the formation of clathrin-coated pits by a reversible translocation of clathrin and its adaptor proteins from the plasma membrane to intracellular vesicles (29). Methyl-bcyclodextrin (MbCD) depletes the membrane cholesterol content (31), wortmannin (Wort) is an inhibitor of phosphatidyl inositol-3-phosphate (PI3K), an enzyme required for the completion of macropinocytosis $(31,32)$, and rottlerin (Rott) interacts with protein kinase C and inhibits fluidphase endocytosis, which is a mannose receptor-independent and unregulated macropinocytotic pathway (33). When the amount of cell-associated iron is calculated for every condition and then subtracted by the amount of iron found when cellsare treated with Noco and Cyt D (= total block of endocytosis; this value represents the cell surface attached particles only), the percentage of complex uptake inhibition can be calculated (compared with the level of normal cells incubated with the complexes at $37{ }^{\circ} \mathrm{C}$ and also subtracted with the value for Noc and Cyt D-treated cells). Please note that, owing to the subtractions made, these values are merely indicative and cannot be considered as true percentages of uptake and uptake inhibition. Performing these calculations, it was found that CPM greatly inhibits cellular internalization of the complexes. Rott leads to a reduction of $46 \%$, Wort to $31 \%$ and $\mathrm{MbCD}$ to $29 \%$. These data further support the previous conclusions that the complexes appear to be internalized via different endocytic mechanisms, involving clathrin-dependent endocytosis, but also partially fluidphase pinocytosis and macropinocytosis. A more precise elucidation of the endocytic routes is beyond the scope of the current study, but we note that this could be done using cells in which proteins specific for endocytic routes are specifically knocked out (29).

\subsection{Effect of Endorem-Lipofectamine complexes on cell viability.}

In order to evaluate the effect of Endorem complexation with Lipofectamine on cell viability, HeLa cells were exposed to a wide range of particle concentrations $(0,25,50,100$ and $200 \mu \mathrm{g}$ $\mathrm{Fe} \mathrm{ml}^{-1}$ ) complexed with various ratios of Lipofectamine $\left(2.5,5\right.$ and $10 \mu \mathrm{ml}^{-1}$ for $100 \mu \mathrm{g} \mathrm{Fe}$ $\mathrm{ml}^{-1}$ ). Figure 3 shows the cell viability data obtained after $24 \mathrm{~h}$ incubation measured by an lactate dehydrogenase (LDH) assay (Fig. 3a) and an MTT [(3-(4,5- dimethylthiazol-2-yl)-2,5diphenyltetrazolium bromide] assay (Fig. 3b). The data show that both assays lead to similar results, where any toxic effects are clearer in the MTT assay than in the corresponding LDH assay. This may be due to the fact that these assays assess cell viability by measuring different parameters, such as mitochondrial functionality and cell membrane permeability for the MTT 
and LDH assay, respectively $(34,35)$. The observed differences between these methods may therefore signify that the complexes do not appear to perturb cell membrane integrity, but rather affect mitochondrial functionality. For cells going into apoptosis, this will result in the translocation of cytoplasmic LDH into the extracellular medium.

The data show that free Lipofectamine at the concentrations used does not induce any cytotoxic effects, which is in accordance with the literature, where it has been reported that cytotoxic effects only occur when using concentrations above $10 \mu 1 \mathrm{ml}^{-1}(9,17)$. When using small amounts of Lipofectamine $\left(2.5 \mu \mathrm{ml}^{-1}\right.$ for $\left.100 \mu \mathrm{g} \mathrm{Fe} \mathrm{ml} \mathrm{m}^{-1}\right)$, none of the complexes appear to have any effect on cell viability up to $200 \mu \mathrm{g} \mathrm{Fe} \mathrm{ml}^{-1}$, which is in line with previous work $(14,15)$. For medium Lipofectamine concentrations $\left(5 \mu 1 \mathrm{ml}^{-1}\right.$ for $\left.100 \mu \mathrm{g} \mathrm{Fe} \mathrm{ml}{ }^{-1}\right)$, cell viability significantly decreased when incubated at the highest concentration of Endorem (200 $\left.\mu \mathrm{g} \mathrm{Fe} \mathrm{ml} l^{-1}\right)$. For the highest Lipofectamine concentrations $\left(10 \mu \mathrm{ml}^{-1}\right.$ for $\left.100 \mu \mathrm{g} \mathrm{Fe} \mathrm{ml} l^{-1}\right)$, cell viability decreased in an Endorem concentration-dependent manner, significantly decreasing cell viability at amounts larger than $100 \mu \mathrm{g} \mathrm{Fe} \mathrm{ml}^{-1}$. Regarding the precise mechanism involved in the induction of cell death, it is interesting to note that high concentrations of Endorem (500 or $1000 \mu \mathrm{g} \mathrm{Fe} \mathrm{ml}^{-1}$ ) with low amounts of Lipofectamine led to much higher cellular iron contents than the values obtained here, but did not induce any cytotoxic effects (9). As the observed toxicity effects correlate with the occurrence of high amounts of cellassociated aggregates (Figs 1a and 2a), it can probably be assumed that the substantial aggregation and cell surface covering by the complexes impair cell homeostasis, as has also been observed for various types of quantum dots (19).

\subsection{Confocal analysis of complex internalization.}

To complement the IONP cell adhesion and uptake studies by quantitative iron determination, confocal laser scanning microscopy was selected to further evaluate the precise intracellular localization of the particles and their uptake routes. To reduce the number of aggregates and as high intracellular iron contents might affect fluorescence-based analysis (9), HeLa cells were incubated with complexes at $25 \mu \mathrm{g} \mathrm{Fe} \mathrm{ml}{ }^{-1}\left(1.25 \mu \mathrm{ml}^{-1}\right.$ Lipofectamine) for $4 \mathrm{~h}$. Following incubation with the various pharmacological endocytic inhibitors, the presence of Endorem was shown by immunostaining for dextran, followed by confocal analysis (Fig. 4). 
In all conditions, surface-associated complexes can be seen, surrounding the cell cytoplasm. In line with the findings described above, treatment of the cells with Noco + Cyt D (Fig. 4e) or incubation at $4{ }^{\circ} \mathrm{C}$ (Fig. 4c) appeared to block nearly all endocytosis. When cells were incubated with Noco alone, some particles were found closer to the cell nucleus, but most remained close to the cell periphery (Fig. 4d), which indicates the need of microtubules to transport the internalized particles from the cell periphery towards the perinuclear region. This is in line with common endocytic transport mechanisms where early endosomes move along the microtubules towards the late endosomes, which are located closer to the perinuclear region $(36,37)$. In accordance to the data obtained for the cellular iron contents, the images show a clear reduction in internalized complexes for cells treated with CPM (Fig. 4i) or Rott (Fig. 4f). Wort (Fig. 4g) and MbCD (Fig. 4h) led to only small effects which were hard to distinguish from control cells incubated at $37^{\circ} \mathrm{C}$. Interestingly, high levels of complexes were found associated with filopodial bridges between HeLa cells (Fig. 4c, bottom right corner), a finding which was also made by Ruan et al. (38), who exposed HeLa cells to TAT-peptide conjugated quantum dots. These filopodia have also been described to be highly active in vesicle shedding and thereby lead to exocytosis of previously internalized particles (38), which could also be the case for Endorem-Lipofectamine complexes.

\subsection{Colocalization of Endorem complexes with endosomal markers.}

Based on the data obtained earlier, the complexes appear to be internalized through clathrinmediated endocytosis, fluid-phase pinocytosis and macropinocytosis. As clathrin-mediated endocytosis is arguably the best characterized endocytic mechanism (39) and has been described to be involved in the internalization of different types of nanoparticles, including IONPs $(14,40)$, this finding correlates well with available literature data. Other, less common, endocytosis pathways, such as caveolin- or flotillin mediated endocytosis, may also participate in the uptake of the complexes and should therefore be looked into. Caveolae are flask-shaped membrane invaginations and are typically associated with cholesterol-rich membrane subdomains called lipid rafts; caveolin-mediated endocytosis is one of the main endocytic pathways for receptor-independent endocytosis. Flotillin-mediated endocytosis is a recently described endocytic uptake mechanism, typical for heparan sulfate proteoglycan receptors, and has been described as mediating the uptake of cationic macromolecules such as 
polyethylenimine (41). The use of pharmacological endocytosis inhibitors, however, can sometimes be somewhat misleading as, for some of them, their effect can differ between cell types (29). In addition, for several endocytic pathways, such as caveolin- or flotillin-mediated endocytosis, no good (noncytotoxic and $100 \%$ specific) pharmacological inhibitors are commonly available. In order to further unravel the mechanisms involved in the internalization of the complexes, the intracellular localization of internalized complexes was correlated with those of marker proteins, specific for distinctive endocytic processes (Fig. 5).

By calculating the number of colocalized pixels for TA-IONP complexes and cellular markers, the degree of colocalization can be estimated (percentage of green pixels that colocalize with red pixels). Caveolin $(9 \pm 2 \%)$ - or flotillin $(13 \pm 3 \%)$-mediated endocytosis do not appear to play a significant role (Fig. 5a and b), taking into account the very low levels of colocalization. The latter is somewhat surprising as the flotillin-mediated pathway has been described as involved in the internalization of cationic macromolecules after electrostatic interaction with cell surfacelocated heparan sulfate proteoglycans, which are negatively charged (42). One possible explanation could be that the addition of Lipofectamine could not overcome the net negative surface potential of the complexes and probably only induces local high positive surface charges. The complexes are then probably covered by binding of charged serum proteins, leading to the observed aggregation effects and a shielding of the positive charges, impeding the electrostatic attraction between the complexes and cellular proteoglycans. On the other hand, higher levels of colocalization are found with Lucifer yellow (a marker for fluid-phase pinocytosis, $37 \pm 7 \%$ ) (43) (Fig. 5c) and transferring (Fig. $5 \mathrm{~d}$, clathrin-specific uptake, $41 \pm 8 \%$ ) (39). We note that the reported colocalization percentages underestimate the true level of colocalization owing to the presence of cell surface-associated complexes that are not internalized. Nevertheless, the relative trends are clear and in line with our previous results.

Based on these data, it appears that a large portion of the particles are internalized through fluid-phase pinocytosis, the pathway typically used for noncomplexed Endorem particles. Non-complexed Endorem, however, is not attracted to the cell surface and is internalized rather inefficiently and with very slow kinetics, making it nearly impossible to include these particles in such short exposure conditions as no internalized IONPs can be seen within this short time span (7). As a possible explanation of our results we propose the following hypothesis, which is summarized schematically in Scheme 2. Based on the net negative 
surface potential of the complexes, even at the highest Lipofectamine amount, it is quite likely that a large portion of Endorem particles remains unbound by Lipofectamine (Scheme 2a). a). The Endorem particles that are complexed with high amounts of Lipofectamine probably form relatively large aggregates at the cell surface and are probably not endocytosed (Scheme 2d, see also Fig. 1a). Smaller amounts of Lipofectamine probably lead to smaller complexes that may enter the cells through clathrin-mediated endocytosis or macropinocytosis (Scheme $2 \mathrm{~b}$ and $\mathrm{c})$. After internalization, the endosomal located complexes travel along the microtubules (Scheme 2e), where the complexes will finally enrich in the lysosomal compartments of the cell (Fig. 2f).

\subsection{Effect of internalized complexes on intracellular endosomes.}

The findings above all point to an active endocytic uptake mechanism, which is in line with previous reports in which Endorem complexes have always been found in vesicular structures withinthe cell cytoplasm by means of electron microscopy (44), confirmed by the high levels of colocalization of the complexes and early endosomal antigen 1 (EEA1)-positive early endosomes at early time points (Fig. 6a).

Interestingly, at early time points the cells show a clear punctuate staining pattern of the internalized complexes, indicative of endosomal localization. At later time points, this pattern changes dramatically and the complexes are primarily caught in a broad perinuclear ring-like structure, which also stains positive for lysosomal associated membrane protein 1 (Lamp-1; Fig. 6b). From the transmission image (Fig. 6b4), it can clearly be seen that the complexes seem to have concentrated or evenaggregated intracellularly as they can easily be picked up as optically dense structures. The Lamp-1 staining pattern, depicting lysosomes, is also substantially altered compared with the typical punctuate staining pattern in cells that were not exposed to IONPs (Fig. 6b5). The lysosomes appear to have enlarged in size in order to be able to contain the large IONP structures. The diffuse staining pattern furthermore hints at the possible deformation of the lysosomes. These data are very similar to the findings of Cho et al. (45) using CdTe quantum dots, showing significant cell death caused by intracellular localization of the quantum dots by mechanisms involving lysosomal enlargement and intracellular redistribution at later times. Based on these data, the correct functioning of IONP complex-containing lysosomes remains questionable. The increased toxicity of 
Lipofectamine-Endorem complexes compared with pure Endorem has also been demonstrated in several studies, where the addition of the TA resulted in the inhibition of stem cell differentiation (46), impeded the functionality of PC12 cells (14) and affected the cytoskeleton of primary endothelial cells (9), effects that have not been observed using pure Endorem particles.

The impact of nanoparticles on endocytic transport has already been touched upon by a few studies, where peptide-functionalized quantum dots were found not to undergo endocytic routing typically associated with the natural ligand the quantum dot was coupled with (47). Intra-endosomal aggregation of IONPs has also been described (48) where endocytosed complexes have furthermore been found to affect the normal endocytic lifecycle, e.g. delaying the maturation of late endosomes into lysosomes (44). Taken together, these data indicate that IONP complexes are internalized through typical endocytic pathways, after which they are mostly concentrated in the endolysosomes at later time points. Their intra-endosomal localization furthermore affects the morphology and the typical appearance of endosomes, possibly impeding the normal cellular functionality (45).

\section{Conclusion}

The present study shows that the addition of Lipofectamine to Endorem particles leads to the rapid formation of complexes that are quite stable in physiological saline, independent of the ratio of both components. For every condition, the main part of the surface of the Endorem particles remains free of Lipofectamine, resulting in a net negative surface charge in all conditions. The presence of serum greatly affects the stability of the complexes, where substantial aggregation occurs, the extent of which correlates with the amount of Lipofectamine added. When exposed to cultured cells, the free particles are taken up by fluidphase pinocytosis whereas complexes formed at low Lipofectamine ratios can be internalized by either clathrin-mediated endocytosis or macropinocytosis. The use of larger Lipofectamine amounts primarily leads to surface-associated complexes which seem to hinder efficient internalization. At later time points, the internalized particles concentrate in a diffuse network of lysosomal structures located in the perinuclear region and greatly affect the typical structure and distribution of the lysosomal structures. The present work indicates that the use of transfection agents such as Lipofectamine does not automatically favor more efficient 
internalization. The high level of aggregation in the presence of serum, and the inability of cultured cells to internalize a large portion of surface-associated aggregates, especially for higher amounts of Lipofectamine, hinders their direct use. Differences in cell medium composition, the concentration of Endorem or the ratio of transfection agent over Endorem will greatly influence the described effects. Considerable attention must be paid to the stability of the particles in serum-containing media and on their intracellular behavior and possible effects on the endocytic machinery of the cell.

In light of cytotoxicity of the Endorem-Lipofectamine complexes, the substantial aggregation and cell surface covering by nanoparticles can drastically impair cell homeostasis (19), a phenomenon that warrants the use of adequate safety precautions when employing transfection agents. The size of the aggregates will most likely depend on (a) the concentration of IONPs present, (b) the ratio of Lipofectamine over Endorem and (c) the presence of additional factors, such as serum proteins. This could be investigated further using fluorescence single particle tracking, a microscopy-based technique that was recently reported to be able to characterize nanoparticle aggregation in complex fluids (49). Efficient IONP internalization, which is of primordial importance to allow for accurate MRI assessment of cell migration, can therefore probably be promoted more by reducing the amount of Lipofectamine, simply using solely free Endorem at higher concentrations, incubating the cells with the complexes in small amounts of serum or using other transfection agents that might not induce such heavy aggregation phenomena.

\section{Materials and Methods}

\subsection{Cell culture.}

HeLa cells were cultured in DMEM/F12 medium (Gibco, Invitrogen, Merelbeke, Belgium) supplemented with $10 \%$ fetal calf serum, $1 \%$ penicillin-streptomycin and $2 \mathrm{mM}$ L-Glutamine (Gibco, Invitrogen, Merelbeke, Belgium) in a humidified atmosphere with $5 \% \mathrm{CO}_{2}$ at $37{ }^{\circ} \mathrm{C}$. HeLa cells expressing a tetracycline-inducible dominant negative form of dynamin (HeLa dyn $\mathrm{K} 44 \mathrm{~A}$ ) were maintained in the same medium, further containing $0.2 \mu \mathrm{g} \mathrm{ml}^{-1}$ puromycin, 0.4 $\mathrm{mg} \mathrm{ml}^{-1}$ geneticin (Gibco, Invitrogen, Merelbeke, Belgium) and $1 \mu \mathrm{g} \mathrm{ml}^{-1}$ TET (SigmaAldrich, Bornem, Belgium). When HeLa dyn K44A cells were maintained in culture in the 
presence of TET, only the natural form of dynamin was expressed, leading to fully functional cells. In order to induce expression of the mutant dynamin form, HeLa dyn K44A cells were given medium without any TET for $24 \mathrm{~h}$ prior to exposure of the cells to Endorem.

\subsection{Endorem-Lipofectamine complexation for cell labeling.}

For all magnetic cell labeling experiments, the various TA-IONP complexes were made in PBS, at concentrations of $1000 \mu \mathrm{g} \mathrm{Fe} \mathrm{ml}{ }^{-1}$ of Endorem and 25, 50 and $100 \mathrm{ml} \mathrm{ml}{ }^{-1}$ Lipofectamine. These complexes were then slightly shaken at ambient temperature to allow complex formation, after which part of the stock solution was taken and diluted with complete cell medium to reach the required particle concentrations.

\subsection{Dynamic light scattering and surface charge.}

The hydrodynamic diameter and surface charge of the Endorem (Guerbet, Villepinte, France)-Lipofectamine (Invitrogen, Merelbeke, Belgium) complexes were measured using a Nanosizer instrument (Malvern, Worcestershire, UK). Endorem suspensions in PBS were made with an iron content of $25 \mu \mathrm{g} \mathrm{Fe} \mathrm{ml}^{-1}$ and measured directly or first combined with Lipofectamine at $0.625,1.25$ or $2.5 \mu \mathrm{ml}^{-1}$. Hydrodynamic diameters were measured after 5 min (12 cycles per run) and then repeated every $5 \mathrm{~min}$ for up to $25 \mathrm{~min}$. After $30 \mathrm{~min}$, the surface charge of the complexes was also measured. Data are expressed as mean \pm standard deviation $(n=3)$.

\subsection{DAB-enhanced Prussian blue staining of Endorem-treated HeLa cells.}

HeLa cells were seeded in 12 well plates containing glass coverslips at $5^{*} 10^{4}$ cells per well and allowed to settle overnight. Then, media were aspirated and fresh medium was given containing Endorem-Lipofectamine complexes $\left(100 \mu \mathrm{g} \mathrm{Fe} \mathrm{ml} l^{-1}, 2.5,5\right.$ or $10 \mu \mathrm{lml}$ Lipofectamine) and incubated with the cells for $8 \mathrm{~h}$. Then, media were removed, cells washed three times with PBS and fresh medium was given without any particles and cells were allowed to further incubate overnight. Next, media were aspirated, cells washed twice with PBS and fixed in 2\% paraformaldehyde (PFA) for 15 min at ambient temperature. An adapted DAB-enhanced Prussian blue staining protocol by Schroeter et al. (50) was used in which the cells were incubated with the Prussian blue reagent $[6 \% \mathrm{HCl}$ mixed $(1: 1)$ with $2 \%$ potassium ferrocyanide (II) hydrate; Sigma-Aldrich, Bornem, Belgium] for $45 \mathrm{~min}$ at $37{ }^{\circ} \mathrm{C}$. Finally, the coverslips were mounted on glass microscopy slides and the samples were imaged by optical 
microscopy (Olympus BX51TF, Olympus, Tokyo, Japan) at a 400x magnification. Images were collected using an Infinity 2 camera (BFi Optilas, Alphen aan den Rijn, the Netherlands).

\subsection{Cell viability.}

Cell viability was quantitated by means of both an LDH assay (Promega, Madison, WI, USA) and an MTT assay. To this end, HeLa cells were seeded at 50000 cells per well in 96-well plates and incubated with Endorem-Lipofectamine complexes at 0, 25, 50, 100 or $200 \mu \mathrm{g} \mathrm{Fe}$ $\mathrm{ml}^{-1}$ and 2.5, 5 or $10 \mu \mathrm{ml}^{-1}$ Lipofectamine per $100 \mu \mathrm{g} \mathrm{Fe} \mathrm{ml}{ }^{-1}$. After 2, 4, 8 and $24 \mathrm{~h}$, both an LDH-assay and an MTT assay were performed according to the manufacturer's protocols. Untreated cells were assayed as a control reference, and untreated cells exposed to $0.1 \%$ Triton X-100 for 15 min were used as negative controls. To verify the lack of interference of the Endorem-Lipofectamine complexes with the LDH-assay, particle-incubated cells were also treated with $0.1 \%$ Triton $\mathrm{X}-100$ for $15 \mathrm{~min}$ and were found to lead to similar toxicity levels as the negative controls. For the MTT assay, background levels generated by aggregated Endorem-Lipofectamine complexes were assessed by measuring the absorbance of HeLa cells incubated with the various complexes, but not treated with the MTT salt. This value was then subtracted from the value obtained for complex-treated cells which were incubated with the MTT salt.

\subsection{Quantitative cellular iron determination.}

Quantitative determination of cellular iron contents was carried out by a colorimetric assay using the disodium salt of 4,5-hydroxy-1,3-benzenedisulfonic acid (Tiron; Acros Organics, Geel, Belgium) as described previously (40). HeLa (or HeLa dyn K44A) cells were seeded in 96 well plates at $2 * 10^{4}$ cells per well and allowed to settle overnight and incubated for another $24 \mathrm{~h}$ to let the cells reach logarithmic growth phase and to induce expression of mutant dynamin in HeLa dyn K44A cells. HeLa dyn K44A cells were incubated with medium containing Endorem-Lipofectamine complexes $\left(50 \mu \mathrm{g} \mathrm{Fe} \mathrm{ml}{ }^{-1} ; 1.25,2.5\right.$ or $5 \mathrm{ml} \mathrm{ml}$ Lipofectamine) in the presence or absence of TET for 4 or $24 \mathrm{~h}$ prior to iron determination. HeLa cells were also treated with pharmacological endocytosis inhibitors (see below) or incubated at $4{ }^{\circ} \mathrm{C}$. Endorem-Lipofectamine complexes were also incubated in wells containing cell culture medium, but without any cells.

\subsection{Pharmacological endocytosis inhibitors.}


To study the uptake pathway of Endorem-Lipofectamine complexes in more detail, several pharmacological inhibitors of endocytosis, i.e. Cyt D, Noco, MbCD, Wort, Rott and CPM (Sigma-Aldrich, Bornem, Belgium) were used. The optimal concentration of each type of inhibitor or mixture was first evaluated to maximize their efficacy and rule out any toxic side effects. The following concentrations were then selected: Cyt D, $25 \mu \mathrm{g} \mathrm{ml}^{-1}$; Noco, $20 \mu \mathrm{M}$; MbCD, 5mM; Wort, $100 \mathrm{nM}$; Rott, $2 \mu \mathrm{M}$; CPM, $10 \mu \mathrm{g} \mathrm{ml}^{-1}$. Cyt D+ Noco were also used together at $25 \mu \mathrm{g} \mathrm{ml}^{-1}$ and $20 \mu \mathrm{M}$, respectively. HeLa cells were pretreated with the inhibitors for $1 \mathrm{~h}$ prior to incubation with Endorem-Lipofectamine complexes $\left(25 \mu \mathrm{g} \mathrm{Fe} \mathrm{ml}^{-1} ; 1.25 \mu \mathrm{l}\right.$ $\mathrm{ml}^{-1}$ Lipofectamine), again in the presence of the inhibitors for 4,8 or $24 \mathrm{~h}$.

\subsection{Confocal analysis of particle uptake.}

HeLa cells were seeded in 12 well plates containing glass coverslips at $5^{*} 10^{4}$ cells per well and allowed to settle overnight. After pharmacological endocytosis inhibitor pre-treatment, HeLa cells were exposed to Endorem-Lipofectamine complexes $\left(25 \mu \mathrm{g} \mathrm{Fe} \mathrm{ml}{ }^{-1} ; 1.25 \mu \mathrm{ml}^{-1}\right.$ Lipofectamine) for $4 \mathrm{~h}$, after which the cells were incubated with $5 \mu \mathrm{g} \mathrm{ml}^{-1}$ Cell Mask Orange (Molecular Probes, Merelbeke, Belgium) for $5 \mathrm{~min}$ at $37^{\circ} \mathrm{C}$, followed by fixation of the cells in $2 \%$ PFA and permeabilization with $0.1 \%$ Triton $\mathrm{X}-100$ for $10 \mathrm{~min}$ at ambient temperature. After fixation and permeabilization, Cell Mask Orange colors the whole cytoplasm. Cells were then blocked in PBS containing 10\% goat serum (Invitrogen, Merelbeke, Belgium) and $2 \%$ bovine serum albumin for $1 \mathrm{~h}$ at ambient temperature. Next, cells were incubated with primary murine antidextran antibody (no. 14533; 1:1000; Stem Cell Technologies, Vancouver, Canada) in blocking solution for $2 \mathrm{~h}$ at ambient temperature, followed by three washing steps with blocking solution and incubation with secondary Alexa Fluor488conjugated goat antimouse antibody (1:250; Molecular Probes, Leiden, the Netherlands) for 1 $\mathrm{h}$ at ambient temperature. Subsequently, cells were washed three times with blocking solution and mounted using ProLong Gold Antifade Reagent containing DAPI (Molecular Probes, Leiden, the Netherlands) for nuclear counterstaining. Samples were imaged with a Nikon C1 confocal laser scanning microscope (Nikon Belux, Brussels, Belgium) and images processed with the Nikon EZ-C1 3.91 imaging software (Nikon Belux, Brussels, Belgium).

\subsection{Confocal analysis of intracellular markers.}

HeLa cells were seeded in 12 well plates containing glass coverslips at $5^{*} 10^{4}$ cells per well and allowed to settle overnight. For short term exposure, cells were then incubated with 
Endorem-Lipofectamine complexes ( $25 \mu \mathrm{g} \mathrm{Fe} \mathrm{ml}{ }^{-1} ; 1.25 \mu \mathrm{ml}^{-1}$ Lipofectamine) for $1 \mathrm{~h}$ at 10 ${ }^{\circ} \mathrm{C}$ followed by a $15 \mathrm{~min}$ chase at $37{ }^{\circ} \mathrm{C}$ in fresh medium not containing any complexes. Cells were then fixed and permeabilized as described above. Next to Endorem, the following markers were also visualized by means of immunocytochemistry: flotillin-1 (polyclonal rabbit antiflotillin-1; no. ab41927, 1:200, Abcam, Cambridge, UK), caveolin-1 (polyclonal rabbit anticaveolin-1; no. ab2910, 1:500, Abcam, Cambridge, UK) and EEA-1 (polyclonal rabbit antiEEA-1; no. ab2900, 1 mgml 1, Abcam, Cambridge, UK). They were detected using a secondary Rhodamine Red-conjugated goat antirabbit antibody (1:250; Molecular Probes, Leiden, the Netherlands). Alternatively, cell media were supplemented with human transferrin conjugated with Alexa Fluor 633 (hTF; Molecular Probes, Leiden, the Netherlands) at $15 \mu \mathrm{g}$ $\mathrm{ml}^{-1}$ or Lucifer yellow $\left(1 \mathrm{mg} \mathrm{ml}^{-1}\right)$ and imaged directly, after immunodetection of Endorem and detection of Lucifer yellow (rabbit IgG antilucifer yellow quenching antibody (Molecular Probes, Leiden, the Netherlands) and secondary Rhodamine Red-conjugated goat antirabbit antibody). For hTF and Lucifer yellow studies, Endorem complexes were incubated together with the endocytic probes at $37{ }^{\circ} \mathrm{C}$ for $30 \mathrm{~min}$ directly. For long-term exposure, HeLa cells were incubated with the complexes for $8 \mathrm{~h}$ at $37{ }^{\circ} \mathrm{C}$, followed by additional incubation overnight in complex-free medium to allow internalization and endocytic routing. After fixation and permeabilization, lysosomes were detected by primary polyclonal rabbit antilamp-1 antibody (no. ab24170, $1 \mu \mathrm{g} \mathrm{ml} \mathrm{m}^{-1}$, Abcam, Cambridge, UK) and secondary Rhodamine Red-conjugated goat-antirabbit antibody (1:250; Molecular Probes, Leiden, the Netherlands). After mounting with ProLong Gold Antifade Reagent containing DAPI, samples were imaged with a Nikon $\mathrm{C} 1$ confocal laser scanning microscope. Colocalization was then analyzed for cell-internalized particles using ImageJ (NIH, USA) and the degree of colocalization was calculated using the colocalization analysis plugin, using 25 iterations and Fay randomization (MBF collection by Tony Collins).

\subsection{Statistical analysis.}

All data are expressed as mean $\underline{ \pm}$ standard deviation unless indicated otherwise. To determine statistical significance of one group with respect to the control (iron uptake) data were analyzed using Student's t-test. In all cases, the degree of significance is indicated when appropriate $(* \mathrm{p}<0.05 ; * * \mathrm{p}<0.01 ; * * * \mathrm{p}<0.001)$. 


\section{Acknowledgements.}

We thank Professor Anna E. Salcini (BRIC, Copenhagen, Denmark) for thorough reading of the manuscript and providing the HeLa Dyn K44A cells. S.J.S. is a post-doctoral fellow from the FWO Vlaanderen. Financial support by the Ghent University Special Research Fund (NB Photonics) is acknowledged with gratitude.

\section{References}

1. Yang X, Grailer JJ, Rowland IJ, Javadi A, Hurley SA, Matson VZ, Steeber DA, Gong S. Multifunctional stable and $\mathrm{pH}-$ responsive polymer vesicles formed by heterofunctional triblock copolymer for targeted anticancer drug delivery and ultrasensitive MR imaging. ACS Nano 2010; 4: 6805-6817.

2. Veiseh O, Kievit FM, Fang C, Mu N, Jana S, Leung MC, Mok H, Ellenbogen RG, Park JO, Zhang M. Chlorotoxin bound magnetic nanovector tailored for cancer cell targeting, imaging, and siRNA delivery. Biomaterials 2010; 31: 8032-8042.

3. Shubayev VI, Pisanic TR, 2nd, Jin S. Magnetic nanoparticles for theragnostics. Adv Drug Deliver Rev 2009; 61: 467-477.

4. Chen A, Siow B, Blamire AM, Lako M, Clowry GJ. Transplantation of magnetically labeled mesenchymal stem cells in a model of perinatal brain injury. Stem Cell Res 2010; 5: $255-266$.

5. Geraldes CF, Laurent S. Classification and basic properties of contrast agents for magnetic resonance imaging. Contrast Media Mol Imag 2009; 4: 1-23.

6. Tong S, Hou S, Zheng Z, Zhou J, Bao G. Coating Optimization of superparamagnetic iron oxide nanoparticles for high T(2) relaxivity. Nano Lett 2010; 10: 4607-4613.

7. Wilhelm C, Gazeau F. Universal cell labelling with anionic magnetic nanoparticles. Biomaterials 2008; 29: 3161-3174. 
8. Soenen SJ, Hodenius M, De Cuyper M. Magnetoliposomes: versatile innovative nanocolloids for use in biotechnology and biomedicine. Nanomedicine (London) 2009; 4: $177-191$.

9. Soenen SJ, Nuytten N, De Meyer SF, De Smedt SC, De Cuyper M. High intracellular iron oxide nanoparticle concentrations affect cellular cytoskeleton and focal adhesion kinasemediated signaling. Small 2010; 6: 832-842.

10. Bulte JW. In vivo MRI cell tracking: clinical studies. AJR Am J Roentgenol 2009; 193: 314-325.

11. Crabbe A, Vandeputte C, Dresselaers T, Sacido AA, Verdugo JM, Eyckmans J, Luyten FP, Van Laere K, Verfaillie CM, Himmelreich U. Effects of MRI contrast agents on the stem cell phenotype. Cell Transplant 2010; 19: 919-936.

12. Chen YC, Hsiao JK, Liu HM, Lai IY, Yao M, Hsu SC, Ko BS, Chen YC, Yang CS, Huang DM. The inhibitory effect of superparamagnetic iron oxide nanoparticle (Ferucarbotran) on osteogenic differentiation and its signaling mechanism in human mesenchymal stem cells. Toxicol Appl Pharm 2010; 245: 272-279.

13. Lunov O, Syrovets T, Rocker C, Tron K, Ulrich Nienhaus G, Rasche V, Mailänder V, Landfester K, Simmet T. Lysosomal degradation of the carboxydextran shell of coated superparamagnetic iron oxide nanoparticles and the fate of professional phagocytes. Biomaterials 2010; 31: 9015-9022.

14. Soenen SJ, Himmelreich U, Nuytten N, Pisanic TR 2nd, Ferrari A, De Cuyper M. Intracellular nanoparticle coating stability determines nanoparticle diagnostics efficacy and cell functionality. Small 2010; 6: 2136-2145.

15. Soenen SJ, Himmelreich U, Nuytten N, De Cuyper M. Cytotoxic effects of iron oxide nanoparticles and implications for safety in cell labelling. Biomaterials 2011; 32: 195-205.

16. Soenen SJ, De Cuyper M. Assessing iron oxide nanoparticle toxicity in vitro: current status and future prospects. Nanomedicine (London) 2010; 5: 1261-1275.

17. Kustermann E, Himmelreich U, Kandal K, Geelen T, Ketkar A, Wiedermann D, Strecker

C, Esser J, Arnhold S, Hoehn M. Efficient stem cell labeling for MRI studies. Contrast Media Mol Imag 2008; 3: 27-37. 
18. Schafer R, Kehlbach R, Wiskirchen J, Bantleon R, Pintaske J, Brehm BR, Gerber A, Wolburg H, Claussen CD, Northoff H. Transferrin receptor upregulation: In vitro labeling of rat mesenchymal stem cells with superparamagnetic iron oxide. Radiology 2007; 244: 514 523.

19. Kirchner C, Liedl T, Kudera S, Pellegrino T, Javier AM, Gaub HE, Stölzle S, Fertig N, Parak WJ. Cytotoxicity of colloidal CdSe and CdSe/ZnS nanoparticles. Nano Lett 2005; 5: $331-338$.

20. Kim HS, Oh SY, Joo HJ, Son KR, Song IC, Moon WK. The effects of clinically used MRI contrast agents on the biological properties of human mesenchymal stem cells. NMR Biomed 2010; 23: 514-522.

21. Montet-Abou K, Montet X, Weissleder R, Josephson L. Cell internalization of magnetic nanoparticles using transfection agents. Mol Imag 2007; 6: 1-9.

22. Mailander V, Lorenz MR, Holzapfel V, Musyanovych A, Fuchs K, Wiesneth M, Walther P, Landfester K, Schrezenmeier H. Carboxylated superparamagnetic iron oxide particles label cells intracellularly without transfection agents. Mol Imag Biol 2008; 10: 138-146.

23. Dalby B, Cates S, Harris A, Ohki EC, Tilkins ML, Price PJ, Ciccarone VC. Advanced transfection with Lipofectamine 2000 reagent: primary neurons, siRNA, and high-throughput applications. Methods 2004; 33: 95-103

24. Damke H, Baba T, Warnock DE, Schmid SL. Induction of mutant dynamin specifically blocks endocytic coated vesicle formation. J Cell Biol 1994; 127: 915-934.

25. Rocker C, Potzl M, Zhang F, Parak WJ, Nienhaus GU. A quantitative fluorescence study of protein monolayer formation on colloidal nanoparticles. Nat Nanotechnol 2009; 4: 577580.

26. Lacerda SH, Park JJ, Meuse C, Pristinski D, Becker ML, Karim A, Douglas JF. Interaction of gold nanoparticles with common human blood proteins. ACS Nano 2010; 4: $365-379$.

27. Yen HJ, Hsu SH, Tsai CL. Cytotoxicity and immunological response of gold and silver nanoparticles of different sizes. Small 2009; 5: 1553-1561. 
28. Maiorano G, Sabella S, Sorce B, Brunetti V, Malvindi MA, Cingolani R, Pompa PP. Effects of cell culture media on the dynamic formation of protein-nanoparticle complexes and influence on the cellular response. ACS Nano 2010; 4: 7481-7491.

29. Vercauteren D, Vandenbroucke RE, Jones AT, Rejman J, Demeester J, De Smedt SC, Sanders NN, Braeckmans K. The use of inhibitors to study endocytic pathways of gene carriers: optimization and pitfalls. Mol Ther 2010; 18: 561-569.

30. Soenen SJ, Brisson AR, De Cuyper M. Addressing the problem of cationic lipid-mediated toxicity: the magnetoliposome model. Biomaterials 2009; 30:3691-3701.

31. Goncalves C, Mennesson E, Fuchs R, Gorvel JP, Midoux P, Pichon C. Macropinocytosis of polyplexes and recycling of plasmid via the clathrin-dependent pathway impair the transfection efficiency of human hepatocarcinoma cells. Mol Ther 2004; 10: 373-385.

32. Salcini AE. PI3KC2 alpha, a class II PI3K, is required for dynamin-independent internalization pathways. FEBS J 2010; 277: 26-27.

33. Hufnagel H, Hakim P, Lima A, Hollfelder F. Fluid phase endocytosis contributes to transfection of DNA by PEI-25, Molecular therapy. J Am Soc Gene Ther 2009; 17: 14111417.

34. Soenen SJ, De Cuyper M. Assessing cytotoxicity of (iron oxide-based) nanoparticles: an overview of different methods exemplified with cationic magnetoliposomes. Contrast Media Mol Imag 2009; 4: 207-219.

35. Soenen SJ, De Cuyper M. How to assess cytotoxicity of (iron oxide-based) nanoparticles. A technical note using cationic magnetoliposomes. Contrast Media Mol Imag 2011; 6: 153164.

36. van der Goot FG, Gruenberg J. Intra-endosomal membrane traffic. Trends Cell Biol 2006; 16: $514-521$.

37. Bausinger $\mathrm{R}$, von Gersdorff $\mathrm{K}$, Braeckmans $\mathrm{K}$, Ogris $\mathrm{M}$, Wagner $\mathrm{E}$, Brauchle $\mathrm{C}$, Zumbusch A. The transport of nanosized gene carriers unraveled by live-cell imaging. Angew Chem Int Edn Engl 2006; 45: 1568-1572. 
38. Ruan G, Agrawal A, Marcus AI, Nie S. Imaging and tracking of tat peptide-conjugated quantum dots in living cells: new insights into nanoparticle uptake, intracellular transport, and vesicle shedding. J Am Chem Soc 2007; 129: 14759-14766.

39. Tosoni D, Puri C, Confalonieri S, Salcini AE, De Camilli P, Tacchetti C, Di Fiore PP. TTP specifically regulates the internalization of the transferring receptor. Cell 2005; 123:875888.

40. Soenen SJ, Vercauteren D, Braeckmans K, Noppe W, De Smedt S, De Cuyper M. Stable long-term intracellular labelling with fluorescently tagged cationic magnetoliposomes. Chembiochem 2009; 10: 257-267.

41. Glebov OO, Bright NA, Nichols BJ. Flotillin-1 defines a clathrinindependent endocytic pathway in mammalian cells. Nat Cell Biol 2006; 8: 46-U16.

42. Payne CK, Jones SA, Chen C, Zhuang XW. Internalization and trafficking of cell surface proteoglycans and proteoglycan-binding ligands. Traffic 2007; 8: 389-401.

43. Swanson JA, Yirinec BD, Silverstein SC. Phorbol esters and horseradish peroxidase stimulate pinocytosis and redirect the flow of pinocytosed fluid in macrophages. J Cell Biol 1985; 100: 851-859.

44. Arbab AS, Wilson LB, Ashari P, Jordan EK, Lewis BK, Frank JA. A model of lysosomal metabolism of dextran coated superparamagnetic iron oxide (SPIO) nanoparticles: implications for cellular magnetic resonance imaging. NMR Biomed 2005; 18: 383-389.

45. Cho SJ, Maysinger D, Jain M, Roder B, Hackbarth S, Winnik FM. Long-term exposure to CdTe quantum dots causes functional impairments in live cells. Langmuir ACS J Surf Colloids 2007; 23: 1974-1980.

46. Kostura L, Kraitchman DL, Mackay AM, Pittenger MF, Bulte JW. Feridex labeling of mesenchymal stem cells inhibits chondrogenesis but not adipogenesis or osteogenesis. NMR Biomed 2004; 17: 513-517.

47. Tekle C, Deurs B, Sandvig K, Iversen TG. Cellular trafficking of quantum dot-ligand bioconjugates and their induction of changes in normal routing of unconjugated ligands. Nano Lett 2008; 8: 1858-1865. 
48. Thorek DLJ, Chen A, Czupryna J, Tsourkas A. Superparamagnetic iron oxide nanoparticle probes for molecular imaging. Ann Biomed Eng 2006; 34: 23-38.

49. Braeckmans K, Buyens K, Bouquet W, Vervaet C, Joye P, Vos FD, Plawinski L, Doeuvre L, Angles-Cano E, Sanders NN, Demeester J, De Smedt SC. Sizing nanomatter in biological fluids by fluorescence single particle tracking. Nano Lett 2010; 10: 4435-4442.

50. Schroeter M, Saleh A, Wiedermann D, Hoehn M, Jander S. Histochemical detection of ultrasmall superparamagnetic iron oxide (USPIO) contrast medium uptake in experimental brain ischemia. Magn Reson Med 2004; 52: 403-406.

\section{$\underline{\text { Tables }}$}

\begin{tabular}{|c|c|c|c|c|c|c|c|}
\hline \multicolumn{6}{|c|}{ Hydrodynamic diameter (nm) } & \multicolumn{2}{|c|}{$\zeta$-Potential $(\mathrm{mV})$} \\
\hline Time & & $5 \mathrm{~min}$ & $10 \mathrm{~min}$ & $15 \mathrm{~min}$ & $20 \mathrm{~min}$ & $25 \mathrm{~min}$ & $30 \mathrm{~min}$ \\
\hline \multirow[t]{2}{*}{ Endorem } & Mean & 118 & 112 & 119 & 116 & 117 & $-5.99 \pm 0.24$ \\
\hline & $\mathrm{PDI}^{\mathrm{a}}$ & 0.271 & 0.246 & 0.250 & 0.227 & 0.236 & \\
\hline \multirow[t]{2}{*}{ Endo $L$} & Mean & 145 & 138 & 141 & 142 & 139 & $-4.71 \pm 0.31$ \\
\hline & PDI & 0.262 & 0.252 & 0.276 & 0.258 & 0.288 & \\
\hline Endo $\mathrm{M}$ & $\begin{array}{l}\text { Mean } \\
\text { PDI }\end{array}$ & $\begin{array}{c}159 \\
0.374\end{array}$ & $\begin{array}{c}155 \\
0.366\end{array}$ & $\begin{array}{c}156 \\
0.373\end{array}$ & $\begin{array}{c}156 \\
0.348\end{array}$ & $\begin{array}{c}156 \\
0.362\end{array}$ & $-3.87 \pm 0.44$ \\
\hline \multirow[t]{2}{*}{ Endo $\mathrm{H}$} & Mean & 189 & 172 & 213 & 186 & 181 & $-2.45 \pm 0.53$ \\
\hline & PDI & 0.382 & 0.334 & 0.354 & 0.362 & 0.375 & \\
\hline
\end{tabular}




\section{$\underline{\text { Scheme Legends }}$}
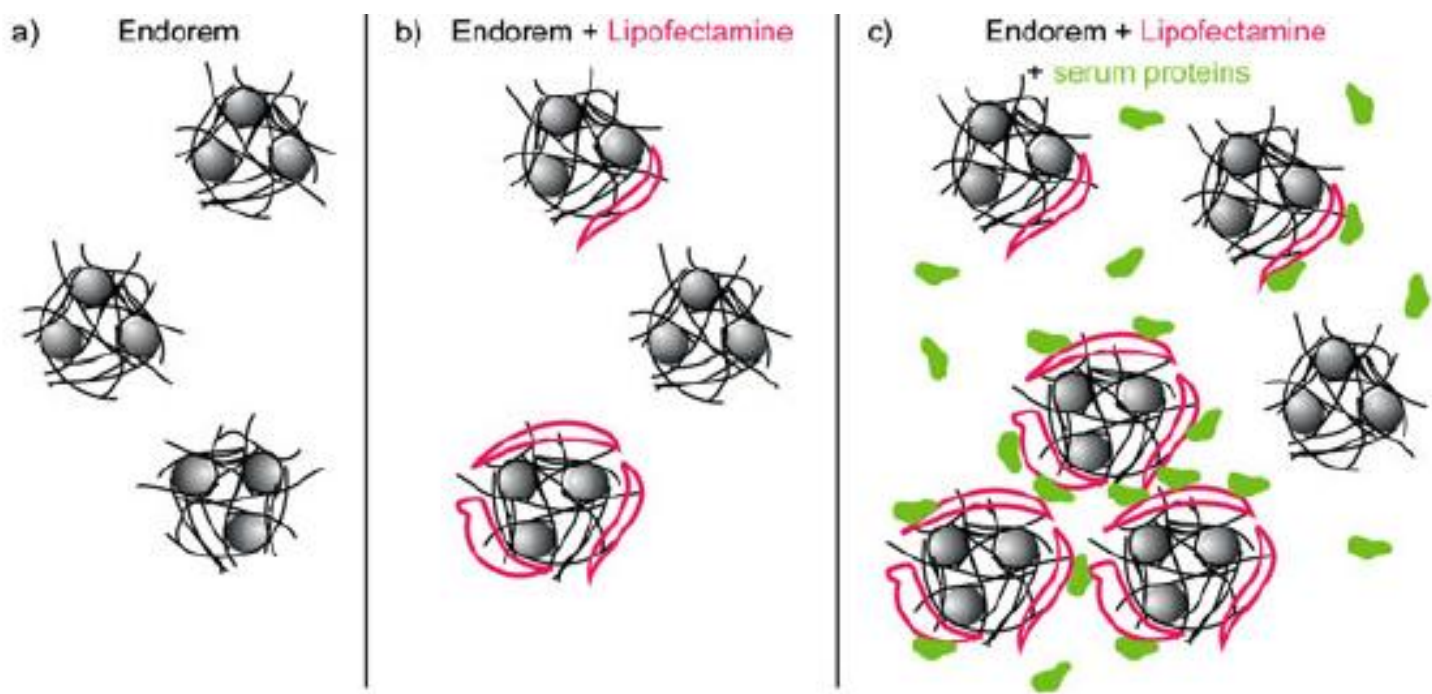

Scheme 1. Schematic overview of (a) free Endorem in saline, (b) Endorem complexed with Lipofectamine in saline, and (c) Endorem complexed with Lipofectamine in serum-containing media. 


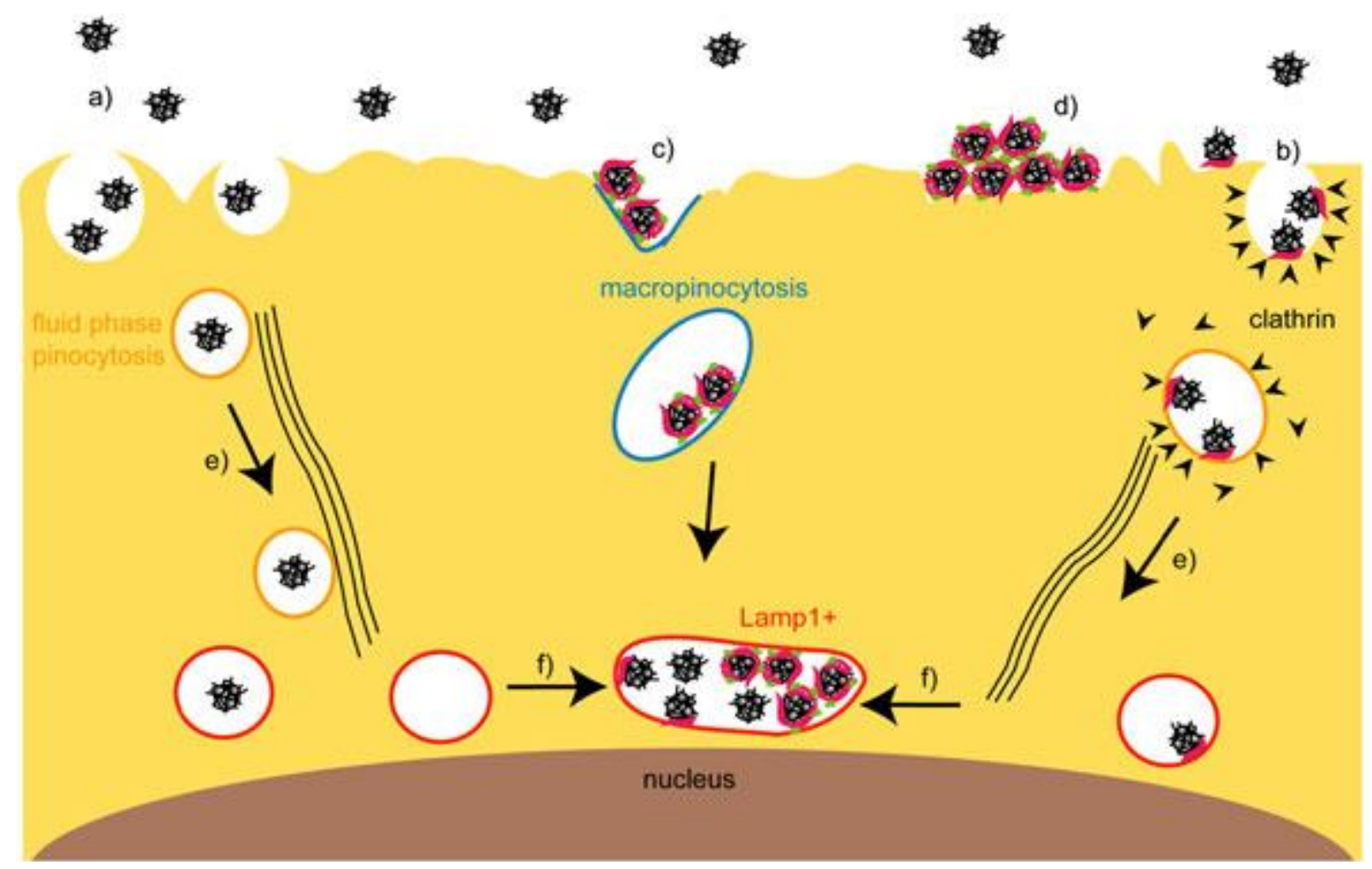

Scheme 2. Schematic overview of the hypothetical model explaining the different interaction processes between cells and Endorem complexes. (a) Free Endorem is taken up by fluid-phase pinocytosis (7), whereas complexes with low TA/IONP ratios are more probably internalized by (b) clathrin-mediated endocytosis or (c) macropinocytosis. The exact internalization pathway may depend on the size of the complexes. (d) Complexes with higher TA-IONP ratios appear to primarily remain attached to the cell surface. (e) Endocytosed complexes are routed along the microtubules towards late endosomes and lysosomes. (f) At later time points, fusion of late endosomes and lysosomes probably results in lysosomal expansion and deformation of mature lysosomes. 


\section{Figure Legends.}
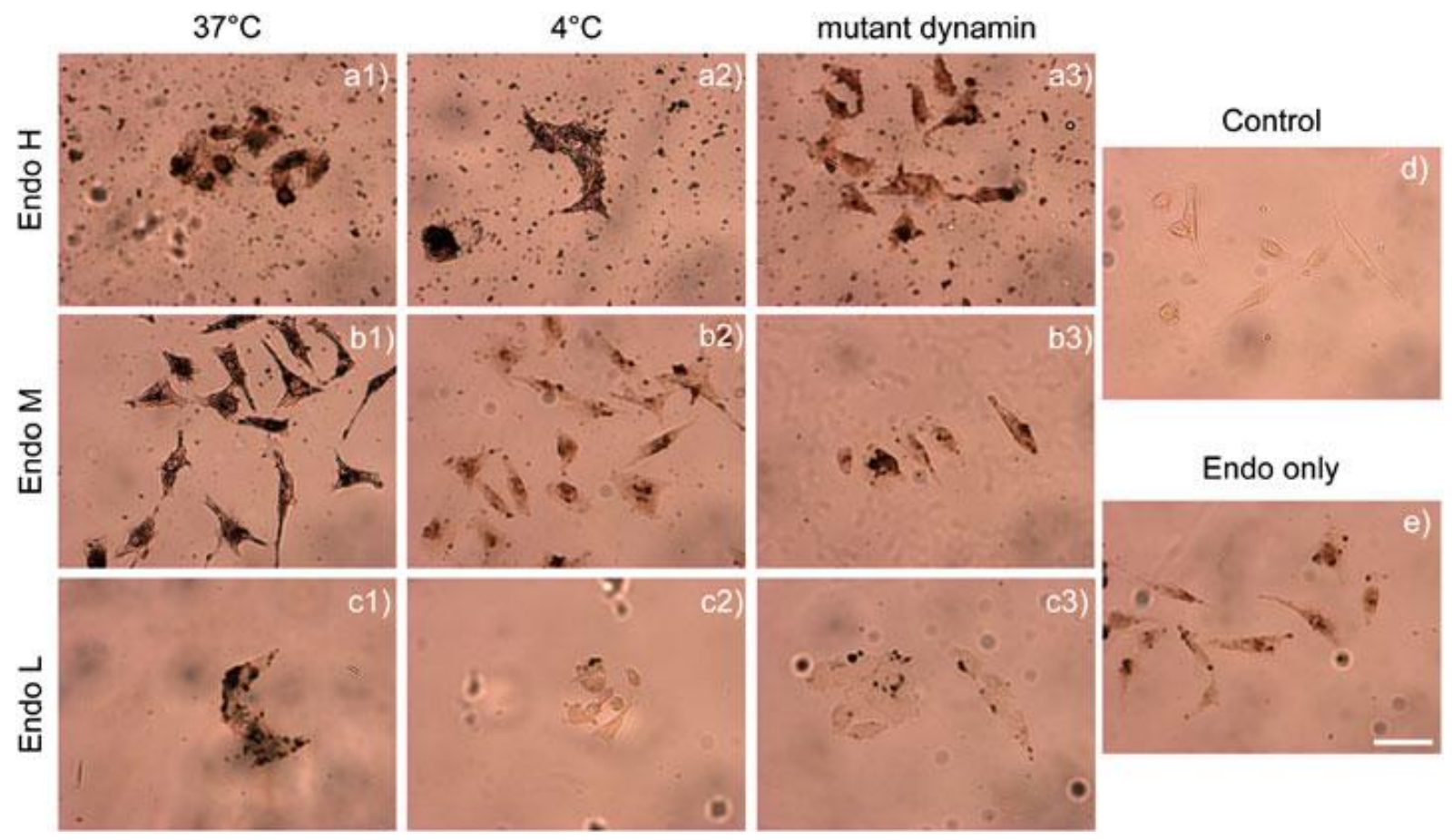

Figure 1. Cellular internalization of Endorem-Lipofectamine complexes occurs via an endocytic process. Representative optical micrographs of DAB-enhanced Prussian blue stained HeLa cells, indicating the presence of iron (brown color). HeLa cells were incubated with Endorem $\left(100 \mu \mathrm{g} \mathrm{Fe} \mathrm{ml}^{-1}\right)$ and Lipofectamine [10 (a), 5 (b) or 2.5 (c) $\mu 1 \mathrm{ml}^{-1}$ ] complexes for $8 \mathrm{~h}$ prior to Prussian blue staining. First row: HeLa cells incubated at $37{ }^{\circ} \mathrm{C}$; second row: incubation at $4{ }^{\circ} \mathrm{C}$; and third row: mutant dynamin expressing HeLa dyn K44A cells incubated at $37{ }^{\circ} \mathrm{C}$. Micrographs of (d) control HeLa cells and (e) HeLa cells incubated with Endorem $\left(100 \mu \mathrm{g} \mathrm{Fe} \mathrm{ml}^{-1}\right)$ for $8 \mathrm{~h}$ at $37^{\circ} \mathrm{C}$ without Lipofectamine. Scale bar: $50 \mu \mathrm{m}$. 

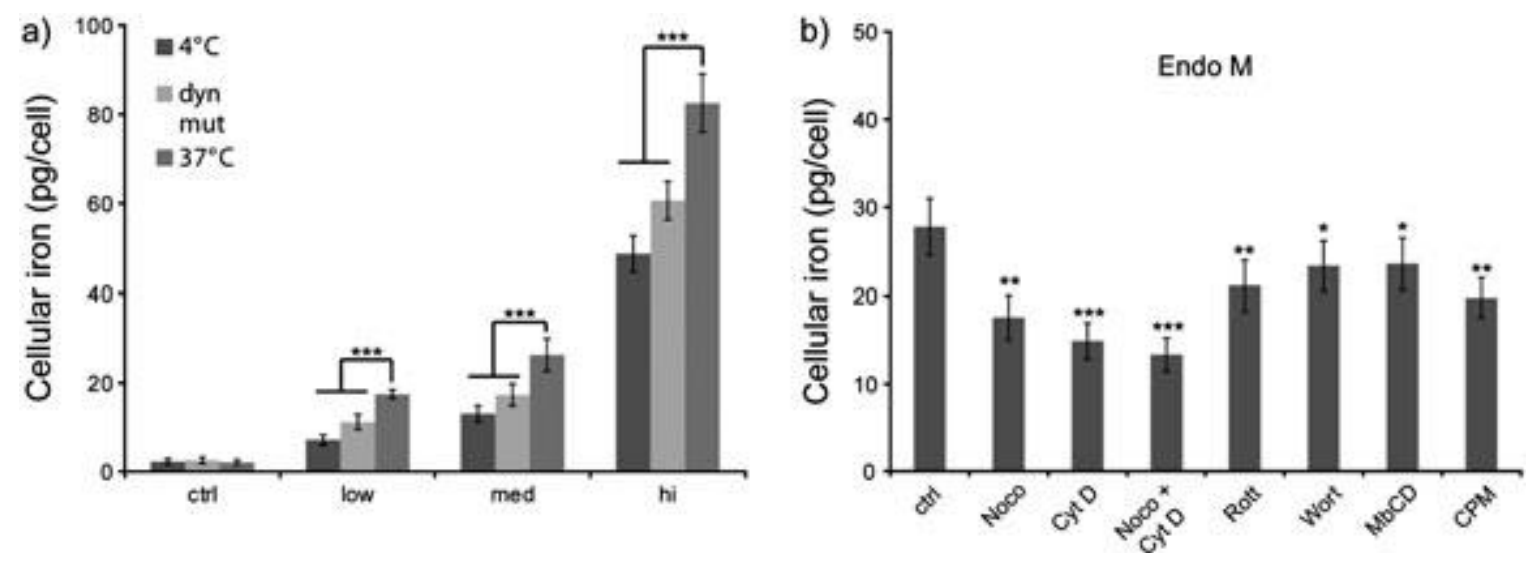

Figure 2. Effects of pharmacological endocytosis inhibitors on Endorem-Lipofectamine uptake. (a) Quantitative cell-associated iron levels for HeLa cells incubated under different conditions: 1) normal HeLa at $4{ }^{\circ} \mathrm{C}$ (dark gray), 2) mutant dynamin HeLa dyn K44A cells at $37{ }^{\circ} \mathrm{C}$ (light gray) or 3) normal HeLa cells at $37^{\circ} \mathrm{C}$ (medium gray) for $24 \mathrm{~h}$ with the various complexes at low, medium and high Lipofectamine ratios. (b) Quantitative cell-associated iron levels after $24 \mathrm{~h}$ for HeLa cells incubated with Endorem-Lipofectamine complexes at medium Lipofectamine contents at $37{ }^{\circ} \mathrm{C}$ in the absence of any other additives or in the presence of pharmacological endocytosis inhibitors: Noco, $20 \mu \mathrm{M}$; Cyt D, $25 \mu \mathrm{g} \mathrm{ml}^{-1}$; Noco + Cyt D, $20 \mu \mathrm{M}$ and $25 \mu \mathrm{g} \mathrm{ml}^{-1}$, respectively; Rott, $2 \mu \mathrm{M}$; Wort, $100 \mathrm{nM}$; MbCD, $5 \mathrm{mM}$; CPM, $10 \mu \mathrm{g} \mathrm{ml}^{-1}$. (a, b) Data are presented as means \pm standard deviation $(n=10)$. The degree of significance for inhibitor-treated cells compared with control cells incubated with the complexes at $37^{\circ} \mathrm{C}$ is indicated where appropriate $\left({ }^{*} \mathrm{p}<0.05, * * \mathrm{p}<0.01, * * * \mathrm{p}<0.001\right)$. 

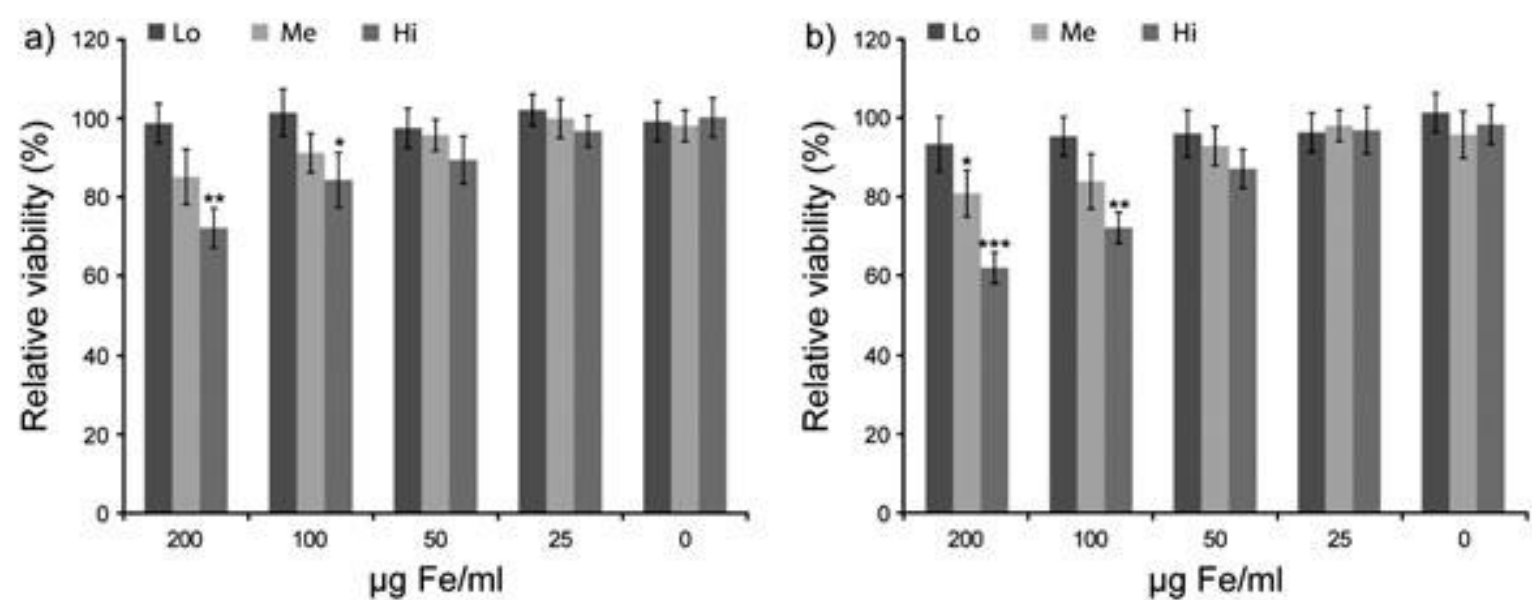

Figure 3. Effects of complex exposure on cell viability. HeLa cells were incubated at $37{ }^{\circ} \mathrm{C}$ with various concentrations of Endorem $\left(0,25,50,100\right.$ or $\left.200 \mu \mathrm{g} \mathrm{Fe} \mathrm{ml}^{-1}\right)$ and Lipofectamine [2.5 (Lo; dark gray), 5 (Me; light gray) or $10 \mu \mathrm{ml}^{-1}$ (Hi; medium gray) per $100 \mu \mathrm{g} \mathrm{Fe} \mathrm{ml}^{-1}$ ] complexes for $24 \mathrm{~h}$ after which the cell viability was assessed by means of (a) an LDH and (b) an MTT assay. Data are presented as relative values compared with untreated control cells as mean \pm standard deviation $(n=10)$. The degree of significance in cell viability between treated cells and untreated cells is indicated where appropriate $\left({ }^{*} \mathrm{p}<0.05,{ }^{* *} \mathrm{p}<0.01\right.$, $* * * \mathrm{p}<0.001)$. 

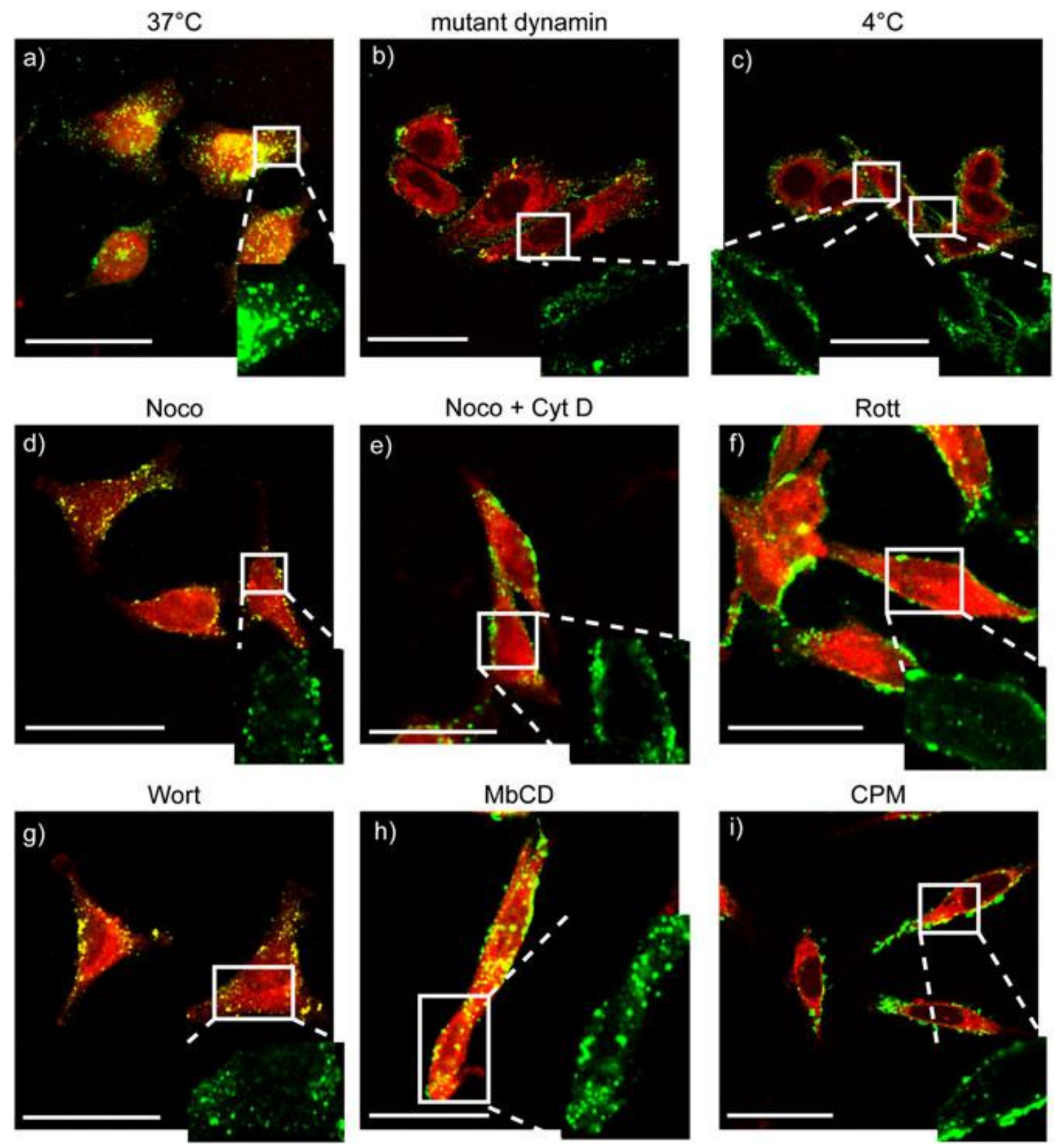

Figure 4. Representative confocal images of HeLa cells incubated with EndoremLipofectamine complexes $\left(25 \mu \mathrm{g} \mathrm{Fe} \mathrm{ml}{ }^{-1} ; 1.25 \mathrm{ml} \mathrm{ml}^{-1}\right.$ Lipofectamine) for $4 \mathrm{~h}$, which were then stained for dextran (green) and cell cytoplasm (orange). The following conditions are shown: (a) HeLa cells incubated at $37^{\circ} \mathrm{C}$; (b) mutant dynamin-expressing HeLa cells, (c) incubated at $4{ }^{\circ} \mathrm{C}$ and in the presence of (d) $20 \mu \mathrm{M}$ Noco, (e) Noco + Cyt D, $20 \mu \mathrm{M}$ and $25 \mu \mathrm{g}$ $\mathrm{ml}^{-1}$, respectively, (f) $2 \mu \mathrm{M}$ Rott, (g) $100 \mathrm{nM}$ Wort, (h) $5 \mathrm{mM} \mathrm{MbCD}$, or (i) $10 \mu \mathrm{g} \mathrm{ml}^{-1} \mathrm{CPM}$. The images shown are merged images of the green and orange channels. In the bottom corner, 
a magnified image (green channel only) is shown of the area indicated by the white rectangle in the main image. Scale bars, $50 \mu \mathrm{m}$. 

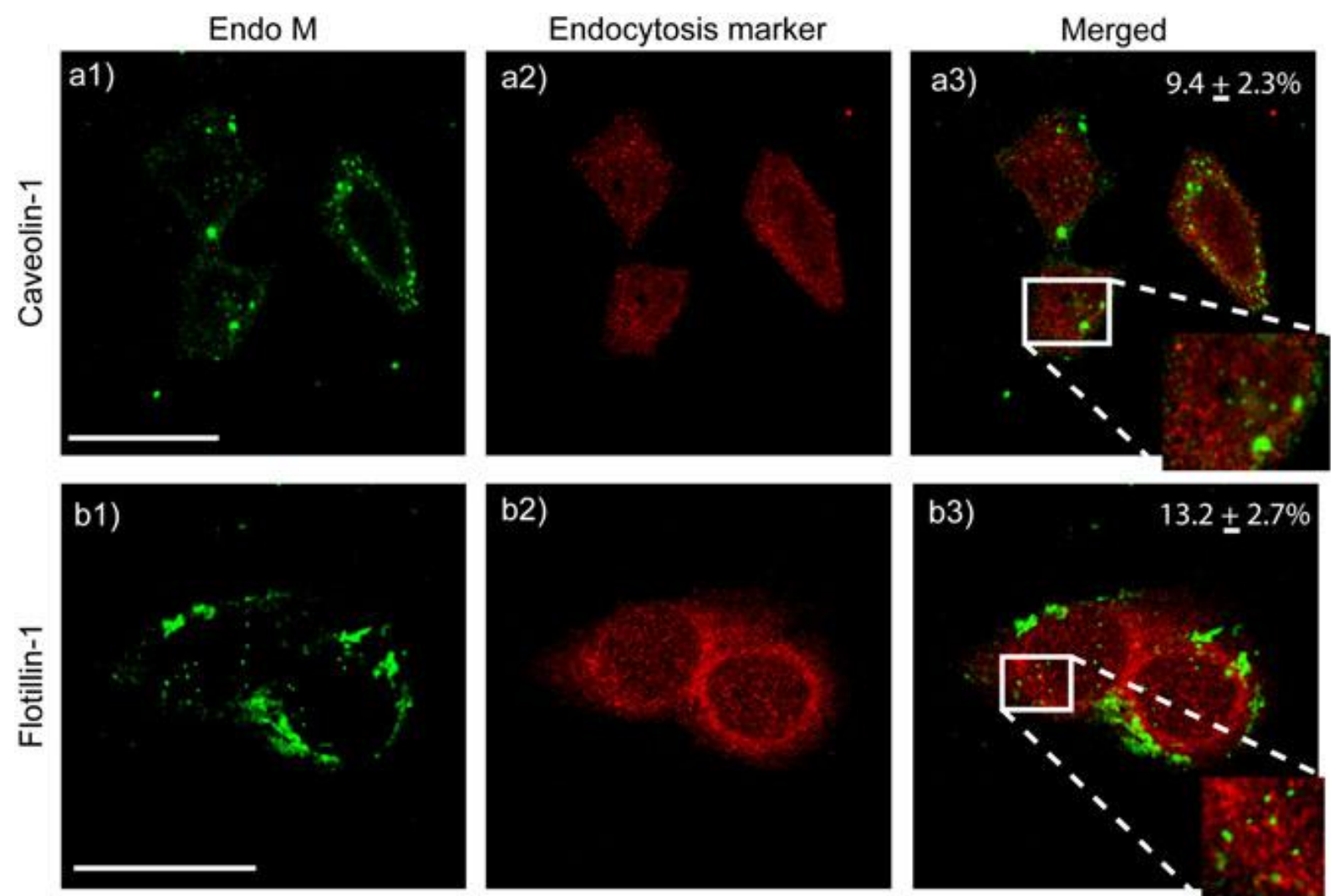

\section{b2)}
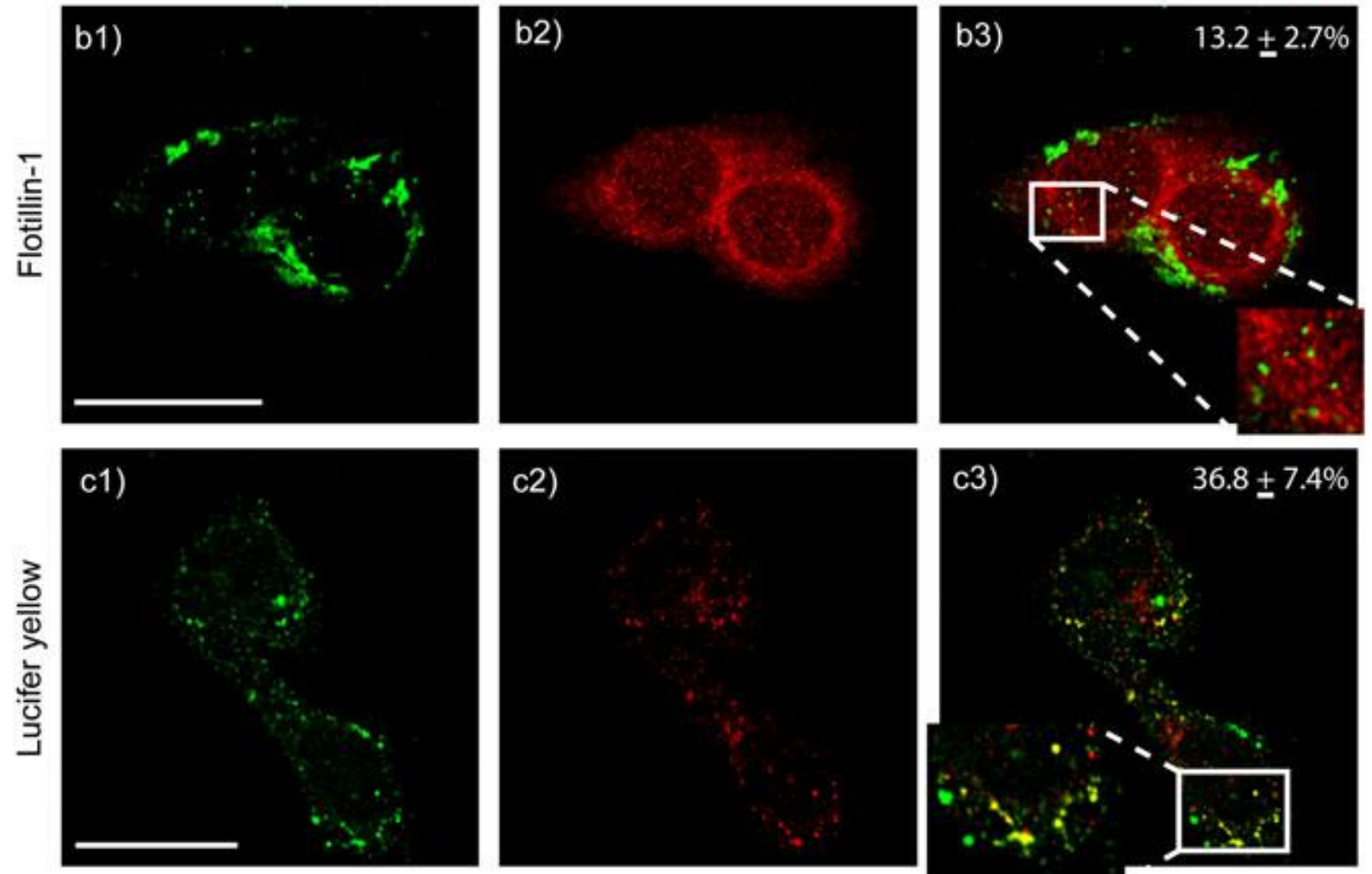

c2)
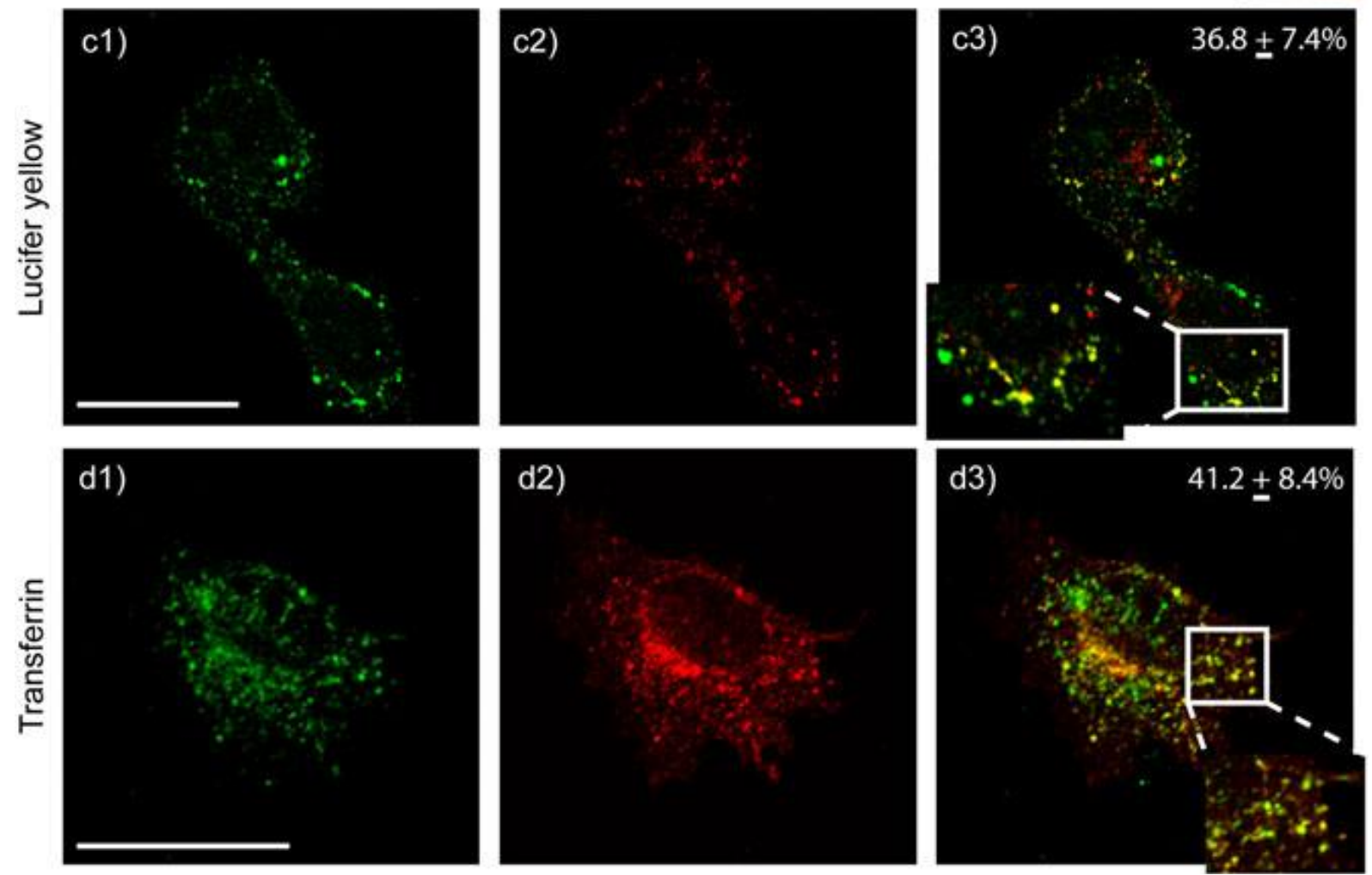

Figure 5. Representative confocal images of HeLa cells incubated with EndoremLipofectamine complexes $\left(25 \mu \mathrm{g} \mathrm{Fe} \mathrm{ml}^{-1} ; 1.25 \mu \mathrm{ml}^{-1}\right.$ Lipofectamine) for (a, b) 15 min or (c, d) $30 \mathrm{~min}$, which were then stained for dextran (green, first row), and intracellular markers 
(red, second row). A merged image of the complexes and the intracellular marker is shown in the third row, where colocalized spots appear in yellow. Images are shown for the following endocytic markers: (a) caveolin-1, (b) flotillin-1, (c) lucifer yellow and d) transferrin. A high magnification image of the area highlighted by a white rectangle in the merged image is shown at the bottom of the image. The number in the top-right corner of the merged images indicates the percentage of colocalization of Endorem with the respective intracellular marker. Scale bars, $50 \mu \mathrm{m}$. 

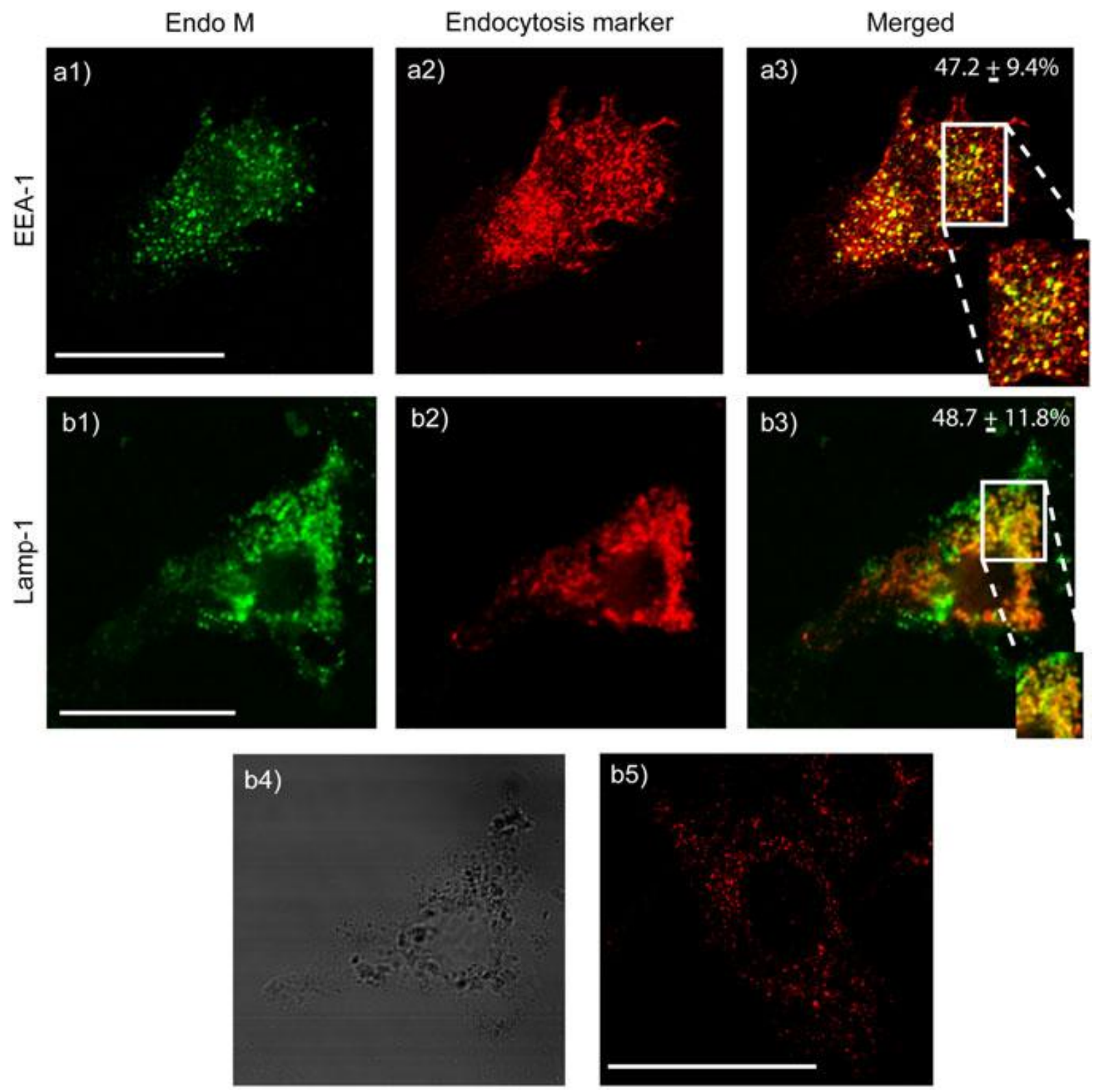

Figure 6. Representative confocal images of HeLa cells incubated with EndoremLipofectamine complexes $\left(25 \mu \mathrm{g} \mathrm{Fe} \mathrm{ml}^{-1} ; 1.25 \mu \mathrm{ml}^{-1}\right.$ Lipofectamine) for (a) 15 min or (b) 8 $\mathrm{h}$ followed by overnight post-incubation in particle free-medium, which were then stained for dextran (green, first row), and intracellular markers (red, second row). A merged image of the complexes and the intracellular marker is shown in the third row, where colocalized spots appear in yellow. Images are shown for the following: (a) EEA-1; (b) Lamp-1. A high magnification image of the area highlighted by a white rectangle in the merged image is shown at the bottom of the image. (b4) The transmission image of the cell shown in (b1-3). (b5) A representative confocal image of an untreated HeLa cell stained for Lamp-1. The 
number in the top-right corner of the merged images indicates the percentage of colocalization of Endorem with the respective intracellular marker. Scale bars, $50 \mu \mathrm{m}$. 